\title{
Brand Management Practices, Corporate Image, Customer Characteristics and Satisfaction among University Students in Kenya
}

\author{
Stephen Maore, \\ Prof. Justus Munyoki, \\ Prof. Mary Kinoti, \\ Dr. Joseph Owino,
}

School of Business, University of Nairobi, Kenya

Doi:10.19044/esj.2019.v15n34p161 URL:http://dx.doi.org/10.19044/esj.2019.v15n34p161

\section{Abstract}

The objective of the study was to determine the influence of brand management practices, corporate image, and customer characteristics on customer satisfaction among university students in Kenya. The study was founded on three theories namely: Customer based brand equity model, expectation confirmation theory and consumer utility theory. The study adopted descriptive research design, the target population comprised of students from all 70 universities registered and accredited to operate in Kenya, with a population of 443,783 students enrolled for various undergraduate degree programmes from which a sample of 384 students was drawnstudent's characteristics in public and private universities tend to differ significantly. The study used a multistage sampling procedure that involved two stages. The first stage was sampling 30\% of the universities in each category using a simple random sampling method. The second stage used systematic random sampling, selecting every 5th student entering the main gate of the main campus of the selected university. Purposeful sampling was applied strategically to ensure equitable distribution of respondents based on gender, the program enrolled and the year of study. This helped reduce biasness and ensured fair representation. Data was analyzed using descriptive statistical analysis, correlation analysis and regression analysis. The study revealed there was a joint effect of brand management practices, customer characteristics and corporate image on customer satisfaction in university students in Kenya with $\mathrm{R}^{2}=0.308 ; \mathrm{p}$-value $=0.000$. Brand management practices were found to influence customer satisfaction more in the private individual owned and private institutional owned than in public universities, with $\mathrm{R}$ square of 0.149 , 0.312 and 0.423 respectively. Similarly, corporate image was found to have a 
stronger moderation effect on the relationship between brand management practices and customer satisfaction in private institutional owned universities as compared to the private individual owned and public universities, with $\mathrm{R}^{2}$ of $0.671,0.440$ and 0.213 respectively. The study recommends that policy can be developed that encourages inculcating brand management practices within universities in Kenya. Policy can be developed to encourage measurement and reporting of performance along brand management practices as used in this study.

Keywords: Branding, Brand Management, Corporate Image, Customer Characteristics, Customer satisfaction

\section{Introduction}

There is a notable neglect of research on branding in higher education. Most of the existing studies have generally focused on branding policies and initiatives in specific institutions or focused on external aspects of branding (Bulotaite, 2003). Herr (2001) explains that in today's higher education landscape, college and university leaders may well consider the principles of brand management to assure their positions vis-à-vis their competitors. This is evident through the use of trademarks to market and promote an institution to the public. Moore (2004) states that institutions have to differentiate themselves depending on the core attributes of the category in which they operate, and makes them different from others in the same category. Differentiation helps an institution get a niche in the market place. For a college or university, the name and all the symbolism attached to it represent the brand.

Various studies have focused on the role of branding on customer satisfaction. However, none has interrogated the influence of customer characteristics on this relationship. For example, Khan, Salman, Nadeem, and Rizwan (2016) found a positive relationship between brand image and consumer purchase intention. Similarly, Graeff (1996) established that whenever a consumer's self-image was similar to the perceived brand image, satisfaction level was enhanced. In a study targeting catering business in Taiwan, Chien-Hsiung (2011) established that customer satisfaction is enhanced if a brand is perceived to be of high value, has favorable characteristics and positive associations. Rory (2000) also concluded that positive brand image leads to increased customer satisfaction and encourage positive recommendations by the users. Similarly, Romaniuk and Sharp (2003) established that brand image directly influences the consumer decision making process and brand choice. Generally, these studies have shown a correlation between brand management practices and customer 
satisfaction, with no emphasis on the moderating effect of customer characteristics in influencing the relationship.

In the universities context, various studies have been done both globally and locally. Globally, Nguyen and LeBlanc (2001) in a crosssectional research involving both the students and faculty members, found out that institutional image influenced faculty and students' loyalty in United States. In a similar study in California, Lamboy (2011) established that brand management promotes the identity of an institution by generating positive memories and linkages with the corporate brand, hence enhancing its distinct competencies. In yet another study, Pinar, Trapp, Girard and Boyt (2011) found a strong correlation between branding initiatives and increase in institutions enrollment in universities in United States. Similarly, Kotecha (2003) established that branding plays a critical role in influencing consumer perception and brand performance in South Africa. Binsardi and Ekwulugos (2003) found out that faculty members and learning facilities critically influenced the students' overall perceptions on the image or reputation of a higher learning institution in United Kingdom.

Locally, Owino (2013) and Waithaka (2014) found that corporate image positively influenced the relationship between service quality and customer satisfaction. However, although these studies focused on the customers as the main unit of analysis, there is no clear indication that the branding initiatives led to customer satisfaction or preference towards the institutions of higher education.

From the above analysis, it is clear that there were gaps that range from contextual, conceptual and methodological. The researcher established that the influence of brand management practices on customer satisfaction in the higher education institutions has not received sufficient attention. This study therefore intended to establish the role of brand management practices in influencing customer satisfaction in universities in Kenya, with corporate image and customer characteristics as the mediating and moderating variables respectively. The main objective of this study was to determine the joint influence of brand management practices, corporate image and customer characteristics on customer satisfaction in the higher education sector in Kenya.

\section{Literature Review}

According to Aaker (1991), the overall purpose of branding is to give a brand a distinct identity that distinguishes it from other competing brand. It stimulates creation of awareness to enable consumers recognize and distinguish a brand from others. Branding adversely influences the consumer decision making process by bringing three advantages; choice advantage; consideration decision, and learning advantage (Keller, 2001). The primary 
step in building brand equity is by creating awareness about the brand through informative communication as a first entry point into the consumers mind. It helps create a favorable position in consumer's memory, enhancing familiarity hence giving a reason for the consumer to buy the brand. Simply, it enhances the possibility of the brand to be included in the consumer's consideration set (Gil, Andre's \& Salinas, 2007). Tse (2001a) observes that corporate image directly or indirectly influences consumer brand evaluation hence affecting the level of satisfaction with the band.

Brand management practices contribute to creating more clear and reliable image in customer mind which gradually, result in increased attraction towards an organization's offering. In the long run, such practices influence consumers' judgment towards the brand. The level of satisfaction will depend on the customers' interpretation of the extent to which they perceive the brand has met their expectation. Mitchell (1999) argues that any inconsistency between the promised benefit and the actual benefit will lead to dissatisfaction.

In a different study, Cooil, Keiningham, Aksoy \& Hsu (2007) established that customers' social economic characteristics significantly influenced the relationship between satisfaction and behavioral outcomes such as brand loyalty. A survey of automobile customers on how differences in customer characteristics affects satisfaction threshold was investigated by Mittal and Kamakura (2001) and found out that different consumer groups as determined by their characteristics had different satisfaction thresholds. Similarly, Rachna and Shaw (2002) compared customer characteristics and satisfaction. After a series of analysis, they found that satisfaction ratings did not differ significantly on the basis of consumer characteristics. They established a significant relationship between satisfaction level and customer characteristics.

\section{Conceptual Model}

This study adopted the conceptual framework shown in Figure 1. The conceptual model identifies brand management practices (independent variable); and customer satisfaction (dependent variable). The study sought to measure the combined effect of brand management practices, corporate image (mediating variable) and the customer characteristics (moderation variable) on customer satisfaction among university students in Kenya. 
Figure 1: Conceptual Model

Independent Variabl Dependent Variable

Moderation Variable

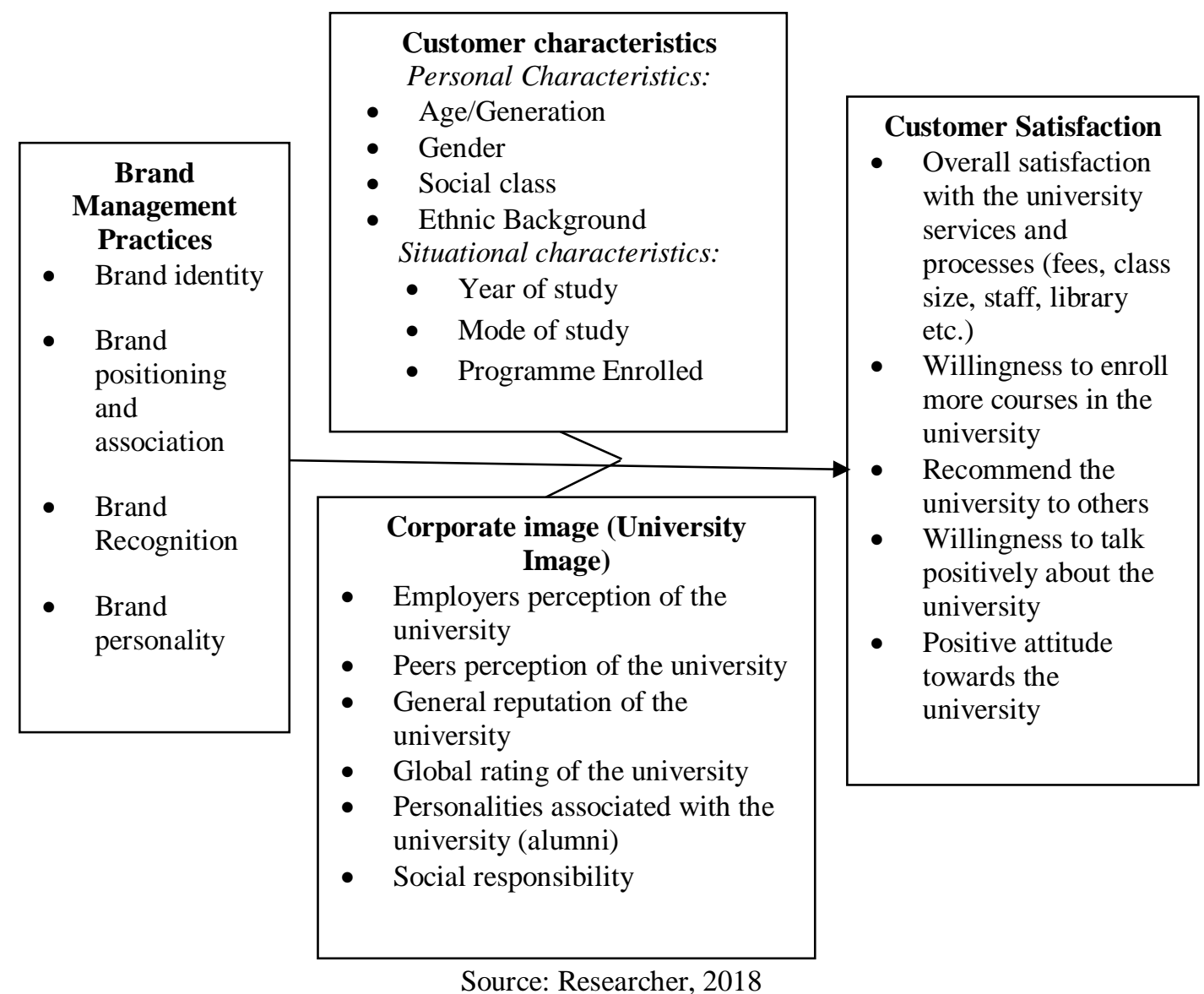

\section{Research Design and Methodology}

To effectively measure the relationship between the dependent and independent variables, this study adopted a descriptive cross sectional survey design. A descriptive cross-sectional survey is appropriate in collecting data to make deductions and conclusions about a population of interest and has been regarded as a representative of the population from which researchers collect data. According to Lomax and Raman (2007), cross-sectional studies have robust effects on relationship studies. Additionally descriptive survey design allows for collection of large data from sizable population. The target population for this study was undergraduate university students in Kenyan local universities. According to the Commission for University Education [CUE] 2015, there were 33 public universities, 18 private individual owned universities and 19 private institutional owned universities making a total of 70 universities registered and accredited to operate in Kenya, with a 
population of 443,783 students enrolled for various undergraduate degree programmes.

To arrive at the sample size of the university students, the researcher used Krejcie and Morgan (1970) sample size determination table. According to the table the appropriate sample size of a population size of 443,783 at $95 \%$ confidence level was 384. Stratified sampling method was used to arrive at the sample size required for each category. The study used a multistage sampling procedure that involved two stages. The first stage was sampling $30 \%$ of the universities in each category using a simple random sampling method. The second stage used systematic random sampling, selecting every 5th student entering the main gate of the main campus of the selected university. Purposeful sampling was applied strategically to ensure equitable distribution of respondents based on gender, the program enrolled and the year of study.. The advantage of using this method is that it minimizes errors that occur during sampling therefore increasing the accuracy (Yin as cited by Tim, Brnich \& Jason, 2016).

\section{Study Findings:}

\subsection{Results of Correlation Analyses}

The general objective of the current study was to establish the influence of brand management practices, corporate image, and customer characteristics on customer satisfaction in universities in Kenya. Pearson product moment coefficient technique was used to conduct correlation analysis so as to ascertain the relationship among study variables. The relationship between variables was done for every category of the Universities in Kenya.

The study sought to establish the relationship between variables. The results are presented in Table 4.24.

Table 5. 1: Correlation Analyses Results

\begin{tabular}{llllll}
\hline & & BMP & CI & CC & CS \\
\hline BMP & $\begin{array}{l}\text { Pearson Correlation } \\
\text { CI }\end{array}$ & 1 & & & \\
& Sig. (2-tailed) & & & & \\
& Pearson Correlation & $.420^{* *}$ & 1 & & \\
CC & Sig. (2-tailed) & .000 & & & \\
& Pearson Correlation & .101 & $.220^{* *}$ & 1 & \\
& Sig. (2-tailed) & .053 & .000 & & \multirow{2}{*}{1} \\
& Pearson Correlation & $.479^{* *}$ & $.520^{* *}$ & $.407^{* *}$ & 1 \\
& Sig. (2-tailed) & .000 & .000 & .000 & \\
\hline$* *$ Correlation is significant at the 0.01 level (2-tailed). $\mathrm{N}=325$ &
\end{tabular}

Key: $\mathbf{B M P}=$ Brand Management Practices; $\mathbf{C I}=$ Corporate Image; $\mathbf{C C}=$ Customer Characteristics and $\mathbf{C S}=$ Customer Satisfaction 
Table 1 shows that there is a statistically significant positive correlation between brand management and customer satisfaction among universities in Kenya $(r=.479, \mathrm{p}<0.05)$.

\subsection{Regression Analysis Results: Joint effect of Brand Management Practices, Corporate Image, Customer Characteristics, and Customer Satisfaction}

This study had one broad objective to determine the joint influence of brand management practices, customer characteristics and corporate image on customer satisfaction among university students in Kenya. In order to test the relationship, the following hypothesis was formulated and tested; $\mathrm{H}_{1}$ : There is a significant combined influence of brand management practices, corporate image and customer characteristics on customer satisfaction among students in universities in Kenya. To test this relationship, first the joint influence was undertaken using a stepwise regression analysis. The results of these tests and analyses are presented in Table 5.2.

Table 5. 1: Regression Results of the Joint effect

5.2a) Goodness of Fit

\begin{tabular}{lllll}
\hline Model & R & R Square & Adjusted R Square & $\begin{array}{l}\text { Std. Error of the } \\
\text { Estimate }\end{array}$ \\
\hline 1 & $.488^{\mathrm{a}}$ & .238 & .236 & 1.007 \\
2 & $.623^{\mathrm{b}}$ & .388 & .384 & .904 \\
3 & $.632^{\mathrm{c}}$ & .400 & .395 & .896 \\
\hline a. Predictors: (Constant), BMP & & \\
b. Predictors: (Constant), BMP, CI \\
c. Predictors: (Constant), BMP, CI, CC \\
Source: Researcher (2018)
\end{tabular}

Key: $\mathbf{B M P}=$ Brand Management Practices; $\mathbf{C I}=$ Corporate Image and CS $=$ Customer Satisfaction

5.2b) Anova

\begin{tabular}{lllllll}
\hline Model & & $\begin{array}{l}\text { Sum of } \\
\text { Squares }\end{array}$ & df & Mean Square & F & Sig. \\
\hline 1 & Regression & 114.829 & 1 & 114.829 & 100.815 & $.000^{\mathrm{b}}$ \\
& Residual & 368.004 & 323 & 1.139 & & \\
& Total & 482.833 & 324 & & & \\
\hline 2 & Regression & 187.104 & 2 & 93.552 & 101.908 & $.000^{\mathrm{c}}$ \\
& Residual & 295.729 & 322 & .918 & & \\
& Total & 482.833 & 324 & & & \\
\hline 3 & Regression & 193.095 & 3 & 64.365 & 71.279 & $.000^{\mathrm{d}}$ \\
& Residual & 289.738 & 321 & .903 & & \\
& Total & 482.833 & 324 & & & \\
\hline
\end{tabular}
a. Dependent Variable: CS
b. Predictors: (Constant), BMP
c. Predictors: (Constant), BMP, CI
d. Predictors: (Constant), BMP, CI, CC

Source: Researcher (2018) 
Key: $\mathbf{B M P}=$ Brand Management Practices; $\mathbf{C I}=$ Corporate Image, $\mathbf{C C}=$ Customer Characteristics and CS $=$ Customer Satisfaction; $\mathbf{C C}=$ Customer Characteristics

\section{2c) Coefficients}

\begin{tabular}{ccccccc}
\hline & & \multicolumn{2}{c}{$\begin{array}{c}\text { Unstandardized } \\
\text { Coefficients }\end{array}$} & $\begin{array}{c}\text { Standardized } \\
\text { Coefficients }\end{array}$ & & \\
& Model & B & Std. Error & Beta & t & Sig. \\
\hline 1 & (Constant) & 2.339 & .173 & & 13.512 & .000 \\
& BMP & .475 & .045 & .488 & 10.643 & .000 \\
\hline 2 & (Constant) & 1.595 & .174 & & 9.153 & .000 \\
& BMP & .225 & .048 & .231 & 4.678 & .000 \\
& CI & .447 & .047 & .464 & 9.406 & .000 \\
\hline 3 & (Constant) & 1.417 & .185 & & 7.676 & .000 \\
& BMP & .216 & .048 & .221 & 4.513 & .000 \\
& CI & .424 & .048 & .441 & 8.877 & .000 \\
& CC & .094 & .034 & .115 & 2.732 & .007 \\
\hline
\end{tabular}

a. Dependent Variable: CS

Source: Researcher (2018)

Key: $\mathbf{B M P}=$ Brand Management Practices; $\mathbf{C I}=$ Corporate Image, $\mathbf{C C}=$ Customer Characteristics and CS $=$ Customer Satisfaction; $\mathbf{C C}=$ Customer Characteristics

The summary model on the joint effect of Brand Management Practices, Corporate Image, Customer Characteristics, and Customer Satisfaction is presented below.

$C S=1.417+0.221 B M P+0.441 C I+0.115 C C$

$\mathrm{BMP}=$ Brand Management Practices; $\mathrm{CI}=$ Corporate Image; $\mathrm{CC}=$ Customer Characteristics and CS $=$ Customer Satisfaction;

When considering all the three categories together, as presented in Table 5.2, the results indicates that $23.8 \% \%$ variation in customer satisfaction was explained by brand management practices $\left(R^{2}=0.238\right)$, and brand management practices and corporate image explain $38.8 \%\left(\mathrm{R}^{2}=0.388\right)$. When an additional variable (Customer characteristics) is added, it explains $40.0 \%$ $\left(\mathrm{R}^{2}=0.40\right)$. The adjusted $\mathrm{R}^{2}$ for the joint effect was 0.395 , and the $\mathrm{P}$ values were $0.000,0.000,0.000$ respectively all of which were less than 0.05 and hence statistically significant and consequently, the findings confirmed the relationship thereby supporting hypothesis that there is a significant combined influence of brand management practices, corporate image and customer characteristics on customer satisfaction among university students in Kenya. The changes in $\mathrm{R}^{2}$ in the results for all universities can be explained by the fact that majority of respondents (140) were from public universities category that posted a low effect of the three predictor variables on the independent variable (customer satisfaction).

The study reveals that brand management practices have significant influence on customer satisfaction among university students in Kenya $(\mathrm{R} 2=0.238 ; \mathrm{P}$ value $<0.05)$. The study also establishes that corporate image 
has a significant mediating effect on the relationship between brand management practices and customer satisfaction $(\mathrm{R} 2=0.213$; P value $<0.05)$. Further, the study discloses that customer characteristics have a significant moderating effect on the relationship between brand management practices and customer satisfaction $(\mathrm{R} 2=0.285 ; \mathrm{P}$ value $<0.05)$. Finally, the study revealed there was a joint effect of brand management practices, corporate image, and customer characteristics on customer satisfaction among university students in Kenya (R2=0.400; P value $<0.05)$.

\section{Discussion}

This section presents discussions of the various tests carried out on the study. The literature and the findings are compared and the conclusions of the same explained. The discussion comprise the combined relationship of brand management practices, corporate image, customer characteristics and customer satisfaction.

The objective of this study was to determine the joint influence of brand management practices, customer characteristics and corporate image on customer satisfaction in higher education institutions in in Kenya. The hypothesis of the study was 'there is a joint influence of brand management practices, corporate image and customer characteristics on customer satisfaction among university students in Kenya.' The results from the joint effect was found to be statistically significant, as the findings indicate that $45.8 \%$ variation in customer satisfaction was explained by joint effect of brand management practices, corporate image and customer characteristics $\left(\mathrm{R}^{2}=\right.$ $0.458)$, and brand management practices explain $32.3 \%\left(\mathrm{R}^{2}=0.323\right)$. When an additional variable is added, it explains $45.3 \%\left(\mathrm{R}^{2}=0.453\right)$ whereas, when customer characteristics is added it explains $45.8 \%\left(\mathrm{R}^{2}=0.458\right)$ with the $\mathrm{F}$ values of 42.272, 58.570 and 49.529, and the $P$ values were $0.000,0.000,0.000$ respectively all of which were less than 0.05 and hence statistically significant and consequently, the findings confirmed the objective that brand management practices, corporate image and customer characteristics have a significant combined effect on customer satisfaction, thereby supporting hypothesis that there was a significant combined influence of brand management practices, corporate image and customer characteristics on customer satisfaction among students in universities in Kenya.

The study also established that the joint effect of the three variables (brand management practices, corporate image and customer characteristics) is more pronounced in the private institutional owned universities as compared to private individual owned and public universities. The joint effect is lowest in public universities compared to other two categories. This indicates that students in public universities pay less attention to the branding initiatives by their respective institutions as compared to their private university 
counterparts. This can be explained by the criteria used in selecting students to join the universities. A large majority of public university students are government sponsored hence their choice is limited cluster cut off points as determined by Kenya Universities and Colleges Central Placement Service (KUCCPS). On the other hand, a large majority of private university students have a freedom of choice since private universities determine the admission criteria as long as the student has met the minimum admission criteria as determined by the Commission for University Education (CUE). This implies that branding, corporate image and customer characteristics play a critical role in influencing the choice of a university, hence satisfaction.

These findings are in tandem with Tse (2001) who observes that corporate image directly or indirectly influences consumer selection process hence affecting the level of satisfaction with the brand. Brand management practices contribute to creating more clear and reliable image in customer mind which gradually, result in increased attraction towards an organization's offering. In the long run, such practices influence consumers' judgment towards the brand. The level of satisfaction will depend on the customers' interpretation of the extent to which they perceive the brand has met their expectation. Also Cooil, et al. (2007) established that customers' social economic characteristics significantly influenced the relationship between satisfaction and behavioral outcomes such as brand loyalty. A survey of automobile customers on how differences in customer characteristics affects satisfaction threshold was investigated by Mittal and Kamakura (2001) and found that different consumer groups as determined by their characteristics had different satisfaction thresholds. Similarly, Rachna and Shaw (2002) compared customer characteristics and satisfaction. After a series of analysis, they found that satisfaction ratings did not differ significantly on the basis of consumer characteristics. They established no significant relationship between satisfaction level and customer characteristics.

\section{Conclusion}

The study established a strong positive correlation between brand management practices and customer satisfaction, with corporate image and customer characteristics as a mediating and moderating variables respectively. The management of universities needs to recognize the critical role of branding in influencing the overall satisfaction of their stakeholders, which eventually leads to growth and profitability. Due to the increased competition in the higher education sector, universities must pursue a differentiation strategy. Universities should embrace brand building initiatives in order to improve the institution's visibility in the market. These includes but limited to: establishing a unique identity and culture; developing appealing logos, slogans and corporate colours; identifying and pursuing a clear positioning 
and differentiation strategy; developing and nurturing positive associations; creating brand awareness through marketing communication in order to improve brand recognition; identifying and nurturing an appealing personality characteristics for the institution among other branding initiatives.

The findings of this study can be used by managers in universities who seek to pursue strategic brand management as a strategy to influence customer satisfaction. The study suggest to managers to regularly conduct a brand audit of their university brand in order to establish branding gaps that would be negatively affecting their institutional growth. The study identifies four important brand management practices; brand identity, brand positioning and association, brand recognition and brand personality. In conclusion, all the three elements (brand management practices, corporate image, customer characteristics) were found to significantly influence customer satisfaction.

\section{Suggestions for Further Research}

This study focused only on students as the primary customers of an institution of higher learning. Further research can be carried out encompassing the entire university stakeholders including but not limited to employees, employers, the potential customers, the community among others. This is based on the fact that success of a brand will depend on its ability to win the hearts of all stakeholders. Secondly, the study focused on the universities accredited by the Commission for University Education (CUE). The researcher strongly recommends for future study to look at the role of brand management practices in influencing students' satisfaction in other institutions of higher learning, such as the Technical Vocational Education and Training Institutions (TIVET). This is based on the fact that these institutions target a different category of students and are differently compared to universities.

\section{References:}

1. Aaker, D. (1991). Managing brand equity: capitalizing on the value of brand name. New York: The Free Press.

2. Binsardi, A. \& Ekwulugo, F. (2003). International marketing of British education: research on the students' perception and the UK market penetration. Marketing Intelligence \& Planning. 21(5), 318327. Retrieved from https://doi.org/10.1108/02634500310490265

3. Bulotaite, N. (2003). University heritage - an institutional tool for branding and marketing. Journal of Higher Education in Europe, 28(4), 449-454.

Retrieved

from https://doi.org/10.1080/0379772032000170417

4. Chien-Hsiung, L. (2011). A study on the relationship between the brand image and customer satisfaction in the catering businesses. 
African Journal of Business Management, 5(18), 7732-7739. Retrieved from http://www.academicjournals.org/AJBM

5. Commission for University Education (2015). Universities authorized to operate in Kenya. Nairobi: CUE. Retrieved from http://www.cue.or.ke.

6. Cooil, S., Keiningham, T. L., Aksoy, L. \& Hsu, M. (2007). A longitudinal analysis of customer satisfaction and share of wallet: investigating the moderating effect of customer characteristics. Journal of Marketing, 71(1), 67-83. Retrieved from http://dx.doi.org/10.1509/jmkg.71.1.67

7. Gil, R. B., Andrés, E. F. \& Salinas, E. M. (2007). Family as a source of consumer-based brand equity. Journal of Product \& Brand Management, 16(3), 188-199. Retrieved from https://www.emerald.com/insight/content/doi/10.1108/106104207107 51564/full/html

8. Graeff, T. R. (1996). Using promotional message to manage the effects of brand and self-image on brand evaluations. Journal of Consumer marketing, 13(3), 4-18. Retrieved from https://doi.org/10.1108/07363769610118921

9. Herr, P. (2001). Higher education institutional brand value in transition: Measurement and management issues. Forum Futures, 16(3), 23-26. Retrieved from https://www.semanticscholar.org/paper/Higher-Education Institutional-Brand-Value-in-\%3A-andHerr/33f46b91dcc06c9eee6d56386207a439192e85e6

10. Khan, M., Salman, Z., Nadeem, B. \& Rizwan, M. (2016). The impact of product and service quality on brand loyalty: evidence from quick service restaurants. American Journal of Marketing Research, 2(3), 8494. Retrieved from http://www.aiscience.org/journal/ajmr

11. Kotecha, P. (2003). Branding, mergers, and the future of South African higher education. Pretoria: South African Universities ViceChancellors Association.

12. Krejcie, R. V. \& Morgan, D. W. (1970). Determining sample size for research activities. Educational and Psychological Measurement, 30(1), 607-610. Retrieved from https://doi.org/10.1177/001316447003000308

13. Lamboy, J. V. (2011). Implications of branding initiatives in higher education among trademarked institutions in California. (Doctoral Dissertations, The University of San Francisco, California, USA). Retrieved from https://repository.usfca.edu/cgi/viewcontent.cgi?article=1007\&contex $\mathrm{t}=$ diss 
14. Lomax, W. \& Raman, A. (2007). The official CIM course book: Analysis and Evaluation. London: Routledge.

15. Mitchell, V. (1999). Consumer perceived risk: Conceptualizations and models. European Journal of Marketing, 33(1/2), 163-195. Doi: 10.1108/03090569910249229

16. Mittal, V. \& Kamakura, W. A. (2001). Satisfaction, repurchase intent, and repurchase behavior: investigating the moderating effect of customer characteristics. Journal of Marketing Research, 38(1), 131-142. Retrieved from https://ssrn.com/abstract=2344925

17. Moore, R. M. (2004). The rising tide branding in the academic marketplace. Change: The Magazine of Higher Learning, 36(3), 5661, Doi: 10.1080/00091380409605582

18. Nguyen, N. \& Leblanc, G. (2001). Corporate image and corporate reputation in customers' retention decisions in services. Journal of Retailing and Consumer Services, 8(4), 227-236. Retrieved from https://doi.org/10.1016/S0969-6989(00)00029-1

19. Owino, E. (2013). The influence of service quality and corporate image on customer satisfaction among university students in Kenya.(Unpublished PhD Thesis, University of Nairobi, Kenya).

20. Pinar, M., Trapp, P., Girard, T. \& Boyt, T. E. (2011). Utilizing the brand ecosystem framework in designing branding strategies for higher education. International Journal of Educational Management. 25(1), 724-739. Doi: 10.1108/09513541111172126

21. Rachna, G. \& Shaw, R. N. (2002). Customer characteristics, satisfaction and repurchase intention. ANZMAC Conference Proceedings. Retrieved from https://eprints.qut.edu.au/82093/1/1423706904ANZMAC\%202014\% 20Proceedings.compressed.pdf

22. Romaniuk, J. \& Sharp, B. (2003). Measuring brand perceptions: testing quantity and quality. Journal of targeting, measurement and analysis for marketing, 11(3), 218-229. Retrieved from https://doi.org/10.1057/palgrave.jt.5740079

23. Rory, P. M. (2000). A consumer-orientated framework of brand equity and loyalty. International journal of marketing research. 42(1), 65-78. Retrieved from https://doi.org/10.1177/147078530004200105

24. Tim, B., Brnich, M., \& Jason, N. (2016). Exploring virtual mental practice in maintenance task training. Journal of Workplace Learning. 28(1), 294-306. Retrieved from https://www.ncbi.nlm.nih.gov/pmc/articles/PMC5006952/

25. Tse, A. C. B. (2001a). How much more are consumers willing to pay for a higher level of service? A preliminary survey. Journal of Services Marketing, 15(1), 11-17. https://doi.org/10.1108/08876040110381328 
26. Tse, D. K. (2001b). China's transition and its implications for international business. Journal of International Business Studies, 32(1), 8-21.

Retrieved

from https://www.researchgate.net/publication/313056665_China's_transiti on_and_the_impacts_on_international_business

27. Waithaka, T. W. (2014). Corporate identity management practices, organizational characteristics, corporate image and brand performance of Kenyan Universities. (Unpublished $\mathrm{PhD}$ thesis, University of Nairobi, Kenya).

Retrieved http://erepository.uonbi.ac.ke/handle/11295/77787 